\title{
Mesenchymal stem cells and cardiac repair
}

\author{
Catharina Nesselmann ${ }^{a}$, Nan Ma ${ }^{a}$, Karen Bieback ${ }^{b}$, Wolfgang Wagner ${ }^{c}$, Anthony Ho ${ }^{c}$, \\ Yrjö T. Konttinen ${ }^{\text {d' Hao Zhang }}{ }^{\mathrm{e}}$, Mihail E. Hinescu ${ }^{\text {f, }}{ }^{\text {, Gustav Steinhoff }}{ }^{\mathrm{a}, \text { * }}$ \\ ${ }^{a}$ Department of Cardiac Surgery, University of Rostock, Germany \\ ${ }^{b}$ Institute for Transfusion Medicine and Immunology, Medical Faculty Mannheim, University of Heidelberg, \\ German Red Cross Blood Donor Service Baden-Württemberg - Hessen, Germany \\ ${ }^{c}$ Medizinische Klinik V, Heidelberg University, Germany \\ ${ }^{d}$ Biomedicum Helsinki, Finland \\ ${ }^{e}$ Cardiovascular Institute \& Fuwai Hospital, Chinese Academy of Medical Sciences, P.R. China \\ ${ }^{f}$ Department of Cellular and Molecular Medicine, 'Carol Davila' University of Medicine and Pharmacy, Bucharest, Romania \\ ${ }^{g}$ Victor Babes National Institute of Pathology, Bucharest, Romania
}

Received: July 4, 2008; Accepted: August 1, 2008

- Introduction

- MSC isolation, characterization and standardization

- Isolation from different sources

- Isolation under different culture conditions

- Characterization of MSCs

- Standardization of MSCs

- Mechanisms of cardiac repair

- Differentiation of MSCs towards cardiomyocytes

- Paracrine effect of MSCs

- MSCs and blood vessel regeneration
- MSC integration into the injured myocardium

- Ex vivo manipulation of MSCs

- Pre-treatment with growth factors

- Genetic engineering

- Hypoxia preconditioning

- Pharmacological interventions

- Pre-clinical application on cardiovascular disease

- Clinical application: where are we?

- Summary

\section{Abstract}

Accumulating clinical and experimental evidence indicates that mesenchymal stem cells (MSCs) are promising cell types in the treatment of cardiac dysfunction. They may trigger production of reparative growth factors, replace damaged cells and create an environment that favours endogenous cardiac repair. However, identifying mechanisms which regulate the role of MSCs in cardiac repair is still at work. To achieve the maximal clinical benefits, ex vivo manipulation can further enhance MSC therapeutic potential. This review focuses on the mechanism of MSCs in cardiac repair, with emphasis on ex vivo manipulation.

Keywords: mesenchymal stem cells $\bullet$ ICLCs $\bullet$ regenerative medicine $\bullet$ heart muscle $\bullet$ repair mechanisms $\bullet$ ex vivo cell manipulation

\section{Introduction}

Heart disease remains the number one killer in developed countries and often leads to damage or loss of functional heart tissue. Cell therapy may provide an effective intervention for repair of cardiac injury due to the self-renewing and multipotential nature of specific cells. Mesenchymal stem cells (MSCs) contain a population of cells that are self-renewing, and are capable of differentiating into

*Correspondence to: Gustav STEINHOFF, M.D., Ph.D., Professor of Cardiac Surgery, Director, Department of Cardiac Surgery, University of Rostock, Schillingallee 35, D-18057 Rostock, Germany. multiple mesodermal tissues, including bone, cartilage, fat (Fig. 1) and muscle, including heart muscle [1].

MSCs can be easily isolated by plastic adherence and rapidly expanded ex vivo. MSCs may repair injured myocardium by activating multiple mechanisms. After transplantation, they may trigger production of reparative growth factors as produce many growth

Tel.: +49-381-4946101

Fax: +49-381-4946102

E-mail: gustav.steinhoff@med.uni-rostock.de 
factors, so that growth factors and cytokines are locally produced [2]. They can suppress local inflammation but they can also replace damaged cells. Furthermore, they can contribute to creation of an environment, which favours endogenous cardiac repair. Thus, they have been identified as promising cells in the treatment of many cardiovascular diseases with heart tissue damage as the common denominator. This review mainly focuses on MSC transplantation for cardiac repair. Firstly, we describe MSC isolation, characterization and standardization from different sources such as bone marrow, adipose tissue, umbilical cord blood and mobilized peripheral blood. Then we focus on the mechanism of cardiac repair, shortly outline above to which MSCs contribute, with emphasis on ex vivo manipulation of MSCs prior to transplantation. Finally, the clinical aspects of MSCs to cardiac repair are discussed.

\section{MSC isolation, characterization and standardization}

The term 'mesenchymal stem cell' is commonly applied to plasticadherent cell preparations isolated from bone marrow or other tissues that are positive for a typical panel of MSC surface markers, and that are able to differentiate into different cell types under specific in vitro or in vivo differentiating conditions $[3,4]$. Their relatively simple but at the same time quite unspecific isolation method notoriously leads to certain heterogeneity of the isolated cells. In any case it is commonly accepted that preparations comprise a multipotent adult stem cell population, which is able to differentiate into different mesodermal cell lineages including osteoblasts, chondroblasts, adipocytes and myocytes. On the other hand, their heterogeneity is reflected by the different cellular morphologies and clonal growth patterns of the initial colonies formed [5]. Strictly speaking, MSCs do not fulfil the criteria of 'stem cells', because of the heterogeneous composition and subpopulations coupled with limited evidence for self-renewal capacity. Therefore, these cell preparations have alternatively been named 'mesenchymal stromal cells', 'multipotent mesenchymal stromal cells', 'multipotent stromal cells' or 'mesenchymal progenitor cell' $[6,7]$. The rich nomenclature for MSCs would not be problematic, if all the different names would basically refer to the same type of cell preparation. Then we would be using many alternative names for the same type of plastic-adherent cell preparation. However, the multitude of different protocols for the isolation of MSCs and the discrepancies of the results reported from different laboratories clearly implies that the nonstandardized isolation methods have also led to tremendous functional differences between these cell preparations and that we are literally comparing 'apples and oranges' [8].

\section{Isolation from different sources}

MSCs were originally isolated from bone marrow $[9,1]$, but similar populations have been reported in adipose tissue [10], umbilical cord blood [11], peripheral blood [12], connective tissues of the dermis and skeletal muscle [13]. A recent finding suggested human multipotent adult stem cells can be generated from heart and liver [14]. Furthermore, the criteria currently used for definition of MSCs are also met by cells isolated from other tissues of adult mice such as brain, liver, kidney, lung, thymus and pancreas [15]. Despite the fact that almost every organ seems to contain MSCs, the precise identity of the counterpart of the MSCs in vitro isolates in vivo in the adult remains elusive, although increasing data suggest that MSCs reside within the perivascular zone [16, 17]. Even though there is no doubt that multipotent cells of mesenchymal derivation reside in many different tissues, it is likely that these stem cells are already primed towards differentiation along a specific lineage to form tissue-specific cell types. Thus, isolates from these different organs are likely to produce different MSC subpopulations, the characteristics and behaviour of which are greatly affected by their sources. Indeed, it has been reported that the differentiation potentials and functions vary widely among MSC preparations derived from different origins [18-20].

\section{Isolation under different culture conditions}

Comparison of results of different research groups is further hampered by the lack of standardized post-isolation MSC culture conditions. A huge arsenal of basal culture media is available with different concentrations of animal sera and different growth and differentiation factor additives. Biomaterials, protein coating and culture conditions such as variation of cell density, oxygen tension, mechanical manipulation, number of passages upon culture, etc., all may have a significant impact on the cell preparations. These methods may have implications $(i)$ on the selection and initial composition of different subpopulations generated; (ii) selection of subpopulations for favoured expansion and (iii) continuously evolving genetic and epigenetic modifications of the cultured cells $[5,8,21]$. This is also reflected by reports of different groups that claim that it is possible under strictly defined culture conditions to generate even pluripotent MSCs such as 'multipotent adult progenitor cells' (MAPCs) [22], 'unrestricted somatic stem cells' [23] or 'very small embryonic like' stem cells [24]. These studies indicate that slight experimental modifications lead to the production of very different cell populations.

\section{Characterization of MSCs}

The use of MSCs and comparison of results of different groups is further affected by the lack of specific and standardized set of molecular MSC markers. To tackle this problem, the International Society for Cellular Therapy proposed three minimal criteria to define MSCs [3]: (i) MSCs must be plastic adherent if maintained in standard culture conditions, (ii) MSCs must express CD105, CD73 and CD90, but lack haematopoietic markers such as CD45, CD34, CD14 or CD11b and (iii) MSCs must be capable of differentiating to fibroblasts, osteoblasts, adipocytes and chondroblasts under the corresponding lineage specific in vitro conditions. 
However, these criteria do not seem to be specific for MSCs. Hence, such minimal criteria are useful but further characteristics must be defined for a reliable quality control. Identification of specific markers might facilitate isolation of a homogeneous population as starting material. Markers that have been used for positive selection include STR0-1 [25], CD271 (low-affinity nerve growth factor receptor) [26], CD73 (ecto-5'-nucleotidase, SH3, SH4) and CD105 (endoglin, SH2) [27]. So far, surface markers are suitable for enrichment of MSCs but the resulting cell populations are still heterogeneous for their other properties and the majority of the isolated cells do not give rise to plastic-adherent colonies.

Human MSCs have already found their way into the clinic and might have beneficial effects for the treatment of cardiovascular disorders and in immune modulation. The lack of common standards for preparation of MSCs and the absence of reliable molecular markers for multipotent MSCs have greatly hampered advancement and comparison of results from different laboratories.

Stem cells in adult heart tissue have been demonstrated by the characterization of c-kit positive stem cell populations capable of cardiomyocyte differentiation [28]. However, the characterization of MSC populations in heart tissue is still under investigation focussing on the perivascular and epicardial localization [29]. The recent identification of interstitial Cajal-like cells (ICLC) in myocardium [30-32] discloses an MSC-related stem cell type in the interstitium of the heart muscle. ICLCs (closely) resemble the interstitial cells of Cajal found in the musculature of the digestive tract [33-35]. ICLCs were identified in various cavitary and noncavitary human organs [36, 37] as well as in blood vessels [38, 39]. Immunohistochemistry showed that ICLCs were slightly and inconsistently positive for CD117/c-kit, variously co-expressed EGF receptor and CD34, but appeared strongly positive for vimentin, along their prolongations. Some ICLCs seemed positive for $\alpha$-smooth muscle actin and tau protein, but were negative for nestin, desmin, CD13 and S-100. The possible functional and pathological significance of ICLCs in heart, and the origin and differentiation of myocardial ICLCs are presently unknown. Apparently, the density of ICLCs is higher in atria than in ventricles. Complex relationships of ICLCs' processes with intercalated disks are documented [40], and such nanocontacts could be important because they are in the molecular range interactions.

ICLCs might be viewed as an un-explored population of uncommitted c-kit-positive resident cells. The inconstant c-kit positivity can imply a switching-phenotype behaviour and may correspond to different functional circumstances. Morphogenetic patterning and myocardial remodelling might have some common mechanisms to impose a correct spatiotemporal migration or to maintain a correct topographic pattern in a complex tissue architecture. Short range integrated signalling events involving interstitial-cell-controlled interactions may be important.

\section{Standardization of MSCs}

For the clinical uses of MSCs for cardiovascular diseases, efficient protocols are needed. The clinical grade production necessitates adhering to good manufacturing practices (GMP) to insure the optimal therapeutic potential. It is absolute need to demonstrate not just the safety of the proposed approach but, first and foremost, its feasibility and an acceptable degree of reproducibility for clinical applications. It is clear that to move from the pre-clinical findings of any study dealing with MSCs to a clinical setting it is mandatory to produce the cells in the appropriate manner. So currently a major task is to develop standardized protocols for isolation, expansion, but also characterization (quality control and potency testing).

But to reach the GMP goal, cells have to be cultured in as close to a closed system as possible. Follow GMP criteria, every steps of the process must be well defined and strictly documented: the starting material (tissue origin, separation or enrichment procedures), cell density in culture and medium (foetal calf serum or human serum, cytokines with serum-free medium for target). Analytical methods are needed to assay the active compound and impurities. A major problem, however, is the strict dependence of human MSCs on bovine calf serum, which is obsolete and dangerous in human transplant settings. It is as yet unclear which individual factors are supporting the growth of MSCs. In vitro requirement for MSC growth without serum-derived additives should be clearly defined. The in vitro and in vivo behaviour of the serumdependent MSCs versus the serum-free MSCs should be compared. Quality control of cells at least should consider phenotype, functional potential, microbiological safety, and ensure the cultured cells remain untransformed. In addition, cell cycle analysis, the longevity telomere length and telomerase activity should be analysed which are well-established markers for long-lived cells and generally ensure the plasticity of MSCs. Furthermore, in vitro plasticity of MSCs should be evaluated with standard protocol for bone cartilage and fat differentiation, similarly in vivo ability of a multi-tissues engraftment should be evaluated in the severe combined immunodeficiency (SCID) model. Finally, quality assurance system procedures specific to the production of MSCs as a cell drug must be determined and implemented.

\section{Mechanisms of cardiac repair}

\section{Differentiation of MSCs towards cardiomyocytes}

MSCs exhibit an enormous in vitro expansion capacity and more importantly a broad differentiation potential into not only mesodermal (including osteoblasts, adipocytes and chondrocytes), but also, albeit still controversial, endodermal (hepatocyte-like cells) and ectodermal lineages (neuronal, neuroglial cells) (Fig. 1) [41]. Makino [42] and Toma [43] reported that after treatment with 5-azacytidine rat MSCs differentiated into cardiomyocyte lineages both in vivo and in vitro. Myogenic differentiation of rat MSCs was also detected in vitro after treatment with bone morphogenetic protein (BMP)-2 and fibroblast growth factor (FGF)-4 [44]. MSCs were able to develop into cardiomyocyte-like cells, which expressed the cardiac myocyte markers myosin heavy 


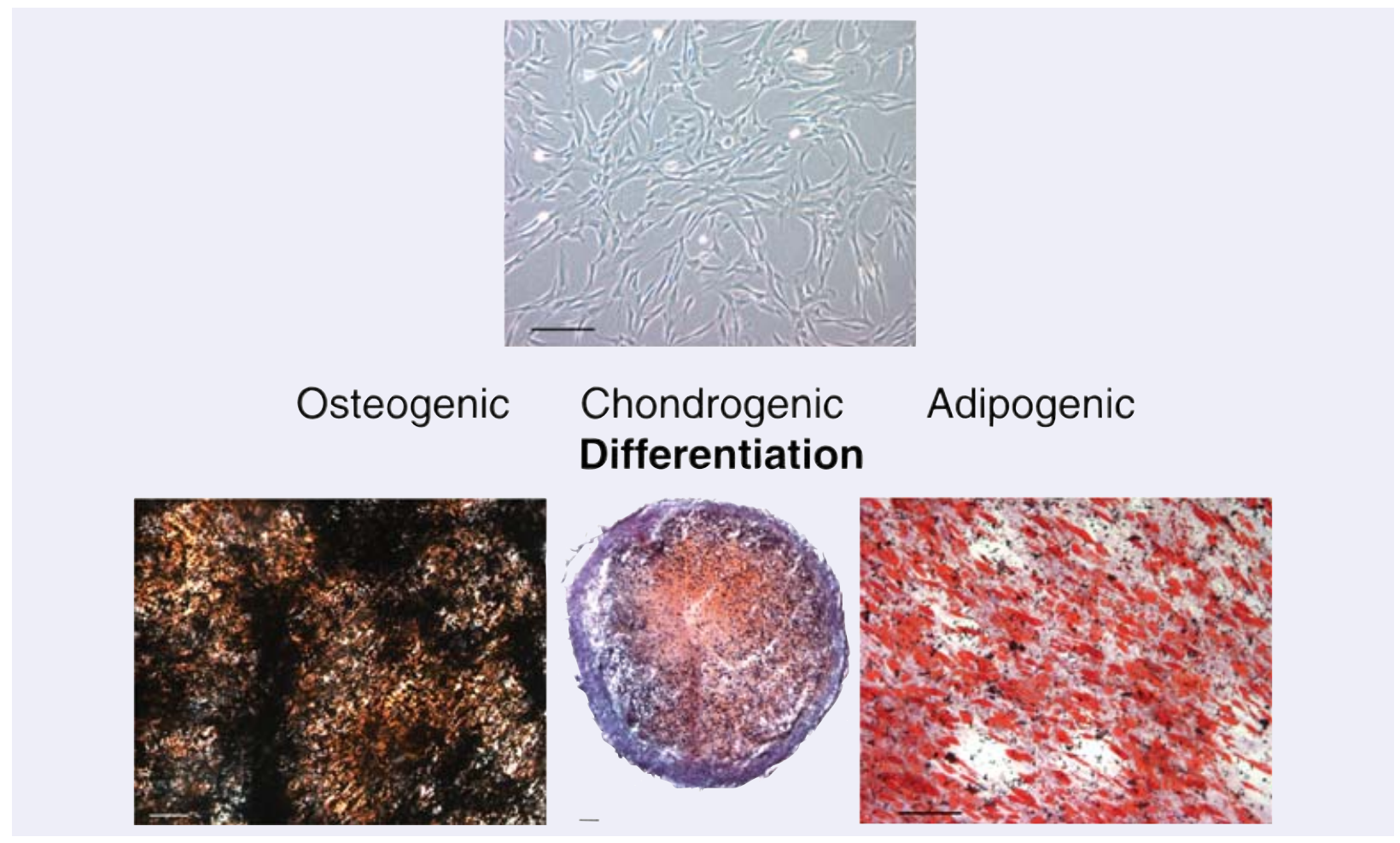

Fig. 1 MSCs exhibit a multidifferentiation potential. Bar $=100 \mu \mathrm{m}$.

chain and troponin $\mathrm{T}$ in cardiomyocyte medium subjected to hypoxia re-oxygenation [45]. If prolonged treatment with hepatocyte growth factor (HGF) was performed, the expression of cardiac-specific markers such as GATA-4, $\alpha$ - and $\beta$-myosin heavy chain and others was reported [46]. Li et al. reported a localization of troponin T in 4'6-diamidino-2-phenylindoldihydrochloride (DAPI)-labelled B-cell lymphoma (Bcl)-2-transduced MSCs in a rat model of permanent ligation of left anterior descending coronary artery [47] indicating a differentiation towards cardiomyocyte-like cells. Despite these promising initial results, the in vitro and in vivo cardiac differentiation of MSCs has been recently re-evaluated. Only a small proportion $(\sim 0.07 \%)$ of bone marrow MSCs in vitro could generate cardiomyocyte-like cells [48], which indicate that MSCs may not generate cardiomyocytes frequently enough for cardiac repair via this mechanism. The following criteria should be considered when justifying MSC transdifferentiation towards cardiomyocyte: $(i)$ the specific cardiomyocyte markers should be expressed, such as cardiac-specific L-type $\mathrm{Ca}^{2+}$ channels, (ii) the specific cardiomyocyte functional properties should be acquired, such as beating, responding to $\mathrm{Ca}^{2+}$ channel-modulating drugs and have functional gap junction and (iii) the cell fusion should be rigorously excluded. However, there is still lack of convincing evidence about human MSC transdifferentiation into functional cardiomyocytes. The role of other mechanisms for promoting functional recovery should be considered.
Verfaillie described that the MAPC, one subset of MSCs, was pluripotent. This population is able to give rise to different cell types with characteristics of visceral mesoderm, neuro-ectoderm and endoderm [49]. When injected into an early blastocyst, a single MAPC could contribute to the development of various tissues [22]. However, the experimental procedure seems to be very difficult to reproduce $[50,51]$. It has been speculated that MAPCs might represent an extremely small subpopulation of cells that must be selected and maintained under very strict conditions for many passages before they can be established [13, 52]. Recently, another subset of MSCs - 'unrestricted somatic stem cells' - was reported by Kogler et al. [23]. These cells were derived from human cord blood and are able to differentiate into many different cell types, including cardiomyocytes.

\section{Paracrine effect}

MSCs secrete a variety of cytokines and growth factors that have both paracrine and autocrine activities. Indeed, all cells secrete various bioactive agents that reflect both their functional status and the influence of their microenvironments. Of utmost interest for clinical application are the differentiation potential, the secretion of paracrine 'trophic' factors as well as the immunoregulatory properties of MSCs. Accordingly paracrine factors secreted by 
MSCs exert anti-apoptotic, pro-angiogenic and endogenous repair effects. The specific homing of MSCs to sites of injury seems to be mediated by chemokines like stromal-derived factor-1 (SDF-1) and HGF (or scatter factor). MSCs express these chemokine receptors and specifically home to sites of injury, including cardiac tissue. For MSCs, analysis of secretion profiles is of specific relevance as secreted molecules might affect direct and indirect effects: direct effects on the MSC preparation themselves, indirectly by inducing other cells in the vicinity to alter their biological properties and functions. Such indirect or trophic effects of MSCs might explain some of the positive therapeutic effects observed with MSCs without any evidence for transdifferentiation of MSCs. For example, such trophic effects have been proposed in treatment of myocardial infarct. The cytokine production of MSCs was studied by cytokine antibody arrays, ELISA and by a cytometric bead array. There were reproducible differences in the chemokine secretion profiles of various MSC preparations but there was no clear concordance. The lack of consistency of different haematopoietic supportive function of MSCs with their chemokine secretory profile underlines the significance of direct cell-cell contact between HPC and MSCs in bone marrow with very specific cellular determinants in maintaining 'stemness'.

Importantly for allogeneic settings, MSCs express low immunogenicity combined with immunosuppressive properties, which suggests that they can safely be used for transplantation without need for a pharmacological immunosuppression to prevent immunological rejection [53]. Their immunomodulatory effects have been demonstrated to affect multiple components of the immune system, but potential specific mechanisms are still under investigation $[54,55]$. In this context the expression and secretion of HLA-G molecules by MSCs is of significant importance in the down-regulation of T-cell alloreactivity [56].

\section{Mesenchymal stem cells and blood vessel regeneration}

Large body of evidence indicates that MSCs could stabilize blood vessel formation and enhance angiogenesis after cardiac injury [57-59] both in in vitro and in in vivo models $[60,61]$. There is a close association between MSCs and vasculature. It is reported MSCs reside in virtually all postnatal organs and tissues. MSC-like cultures from blood vessels alone could be established in vitro [15]. A perivascular niche of postnatal MSCs in human bone marrow, dental pulp and thoracic aortas was found [62]. Physically MSCs near the perivascular site may play a very critical role on the physiological turn over and organ repair. Once injured, they would be activated from the perivascular site, proliferate, and secret trophic factors which favour the tissue repair. The pericyte, a mesenchymal-like cell, emerges as a possible in vivo source for locally therapeutic MSCs.

MSCs could also influence endothelial cell (EC) behaviour and vice versa. The presence of ECs appears to promote MSC differentiation [63-65]. It is well established that MSCs promote EC migration and tube formation [66]. In addition, MSCs seeded on three-dimensional tissue engineering constructs facilitate EC growth. MSCs were able to secrete enough amount of VEGF, the key regulator for angiogenesis and ECs survival [67, 68]. Furthermore, MSCs also express other chemokine and cytokines such as transforming growth factor- $\beta$ and matrix metalloproteases (MMPs; e.g. MMP-2 and MMP-14), which could further mediate the crosstalk between MSCs and ECs [69, 70].

\section{Mesenchymal stem cells and cardiac extracellular matrix}

\section{Failing heart modulates its extracellular matrix}

Most heart diseases gradually tend to evolve towards heart failure. To compensate for this, the heart starts to beat faster (tachycardia) and harder, but also dilates to increase wall tension (preload) between the heart beats (diastole) to increase stroke volume. These compensatory mechanisms seem to work quite well, but in the long run such processes, probably to a large extent via the mechanosensing/transducing apparatus, lead to myocardial degeneration, swelling of the cardiomyocytes and interstitial fibrosis with increase in fibroblasts and extracellular matrix. Such tissue is functionally invalid. There has been a paradigm shift in the treatment of heart failure from ionotropic drugs (strengthening the heart beat) towards control of excessive activation of the compensatory mechanisms, today targeting renin-angiotensin-aldosterone axis and sympathetic nervous system as well as fluid overload. Interestingly, none of these strategies manipulates the outside-in (or inside-out, for that matter) signalling between extracellular matrix and heart cells. Although the current treatment strategy slows down the disease development and relieves symptoms, better understanding of disease pathomechanisms (degenerative medicine) as well as future therapies can be obtained with stem cell research in heart diseases (regenerative/reparative medicine) [71].

\section{Mechanosensors}

For practical reasons most stem cell studies in heart regeneration have focused on cultured cells and soluble factors, like 5-azacytidine, BMP-2, FGF-4 and HGF. Less attention has been paid to ECM, which contains a multitude of cognate ligands for matrix receptors of the heart cells. Indeed, it is a typical feature for mesenchymal cells that they need ECM for survival, which in the absence undergo apoptosis known as anoikis (homelessness). In the MSC research field, increasing attention is being paid to the profound effects of the ECM-cell signalling on cellular adhesion, spreading, migration, proliferation and differentiation, which are of prime importance for stem cell grafting in the heart and their local expansion and differentiation into cardiomyocytes or any of the other pertinent cells in the heart.

Mechanotransduction can be defined as the cellular mechanisms by which load-bearing cells sense physical forces, transduce 
them into biochemical signals, and generate responses to alter cellular structure and function [72]. Mechanotransduction starts with mechanosensing. Probably the most important set of mechanosensors are the integrins located at the lateral cell-ECM contact points (costamers). Integrins form transmembrane links between their extracellular ligands and the intracellular and dynamic microfilamentous actin cytoskeleton. Integrins are covalently coupled, heterodimeric $\alpha \beta$ integral membrane proteins, which always contain one of the $18 \alpha$-subunits and $8 \beta$-subunits. The combinatorial rules are such that they allow formation of altogether 24 different integrin receptors, but alternative splicing generates even more heterogeneity. Cardiomyocytes can at different developmental stages express $\alpha 1-, \alpha 3-, \alpha 5-, \alpha 6-, \alpha 7-, \alpha 9-$, and $\alpha 10$-subunits coupling mainly with $\beta 1$ (either $\beta 1 \mathrm{~A}$ or the striated muscle-specific $\beta 1 \mathrm{D}$ splice variant [73]).

\section{Integrin-mediated signal transduction and integrin plasticity} Integrins are clustered at the costameres described above, overlying the Z-bands. Integrins bind their extracellular ligands, like type I or III collagen. This ligand-receptor binding per se, or secondarily via stretch exerted via it, can lead to outside-in signalling. Due to the signal transduction pathways engaged, this occurs often in cooperation with soluble, juxtacrine or intracrine growth factors and their respective receptors. Integrins do not only sense and transduce signals. They are also themselves regulated so that their levels of expression, profile, binding strength, activity or localization can change. During development from neonatal state to adulthood there is a switch from fibronectin and type I collagen binding towards laminin-binding integrins in rat [74]. Increased expression of integrin subunits $\alpha 1, \alpha 5, \alpha 7, \beta 1 / \beta 1 \mathrm{D}$ has been described upon chronic pressure loading in mice [75].

\section{Dystroglycan complex}

Another cell-matrix contact point protecting the integrity of the sarcolemma is also located at the costamere but built around dystroglycan. The dystroglycan story started from dystrophin, which was first described in muscle dystrophies (as Duchenne/Becker disease) and X-linked dilated cardiomyopathy. Cytoplasmic dystrophin mediates coupling of the contractile actin cytoskeleton with the sub-sarcolemmal dystroglycan complex. The cystein-rich region towards the other end of dystrophin binds to the intracytoplasmic tail of the transmembrane $\beta$-dystroglycan in the dystroglycan complex. The other, extracellular end of $\beta$-dystroglycan binds the extracellular $\alpha$-dystroglycan, which again is bound to laminin-211. For a more complete structure and other components of the dystroglycan complex, including neuronal nitric oxide synthase (nNOS) and caveolin-3, see Liew and Dzau [76].

\section{Adhesion receptors in MSCs}

Naive MSCs and other stem cells, such as embryonic stem cells or induced pluripotent stem cells, must be administered to the tissue so that they can access the injured heart. Intravenous, intra-arterial and transmural administration as well as mobilization of eventual endogenous stem cell reservoirs have been tried. Intravenous administration would be the most convenient route of administration, presuming that the infused cells reach the target tissue. In the early phases of transmigration, intravascular MSCs start to tether and roll along the endothelium, a process mediated by carbohydrate-lectin interactions; endothelial P-selectin, with an unknown MSC counterligand, has been suggested to play a role for MSCs [77]. This close contact with the ECs may expose MSCs, which carry, e.g. CXCR4 chemokine receptors, to various chemokinetic/chemotactic stimuli, such as chemokines, e.g. CXCL12, and alarmins (danger-associated molecular patterns released from necrotic and/or activated cells). This activates and up-regulates the MSC integrin receptors [78]. Integrin subunits $\alpha 1, \alpha 2, \alpha 3, \alpha v, \beta 1, \beta 3$ and $\beta 4$ have been described in human MSCs [1]. The process then continues, perhaps mainly via firm Int $\alpha_{4} \beta_{1}$-dependent binding to endothelial vascular cell adhesion molecule (VCAM)-1 [77], followed by transmigration into tissue. In the tissues the interstitial MSCs meet other sets of matrix molecules as outline above, which guide them further, which have been much less studied. The relatively poor engraftment in the injured heart after i.v. infusion of MSCs suggests that the cells to be transplanted should be 'tailored' in vitro, perhaps by appropriate isolation, expansion or pre-treatment procedure (see below under section 'Dehydroepiandrosterone' [DHEA]), for an appropriate set of adhesion molecules, in particular the integrins. Using modern high throughput technologies [79], it has been shown that all organ and tissue sites have their vascular 'zip codes' [80] so targeted delivery should be possible.

\section{Ex vivo manipulation of MSCs}

\section{Pre-treatment of MSCs with growth factors}

There are different approaches for MSC manipulation (Fig. 4). The low cellular survival rate and transdifferentiation potency of MSCs after cardiac transplantation engenders only marginal functional improvement by directed recruitment and replacement of lost myocardiocyte cell mass $[43,81]$. Thus, interventions that would facilitate differentiation and enhance the cytoprotective effects of MSCs could form a rational approach against the arduous microenvironment incurred from ischaemia, inflammatory response. To improve efficacy of MSC transplantation, the role of growth and differentiation factors to expand the stem cells and to facilitate their engraftment into cardiac tissue has been recently studied, including FGF-2, insulin-like growth factor (IGF)-1 and BMP-2 [82-85].

Combination of these growth factors might greatly facilitate differentiation of MSCs into cardiomyocytes. Furthermore, an antiapoptotic signal was delivered by many growth factors, and the expression of connexin-43 was increased [86]. Pre-treatment of 


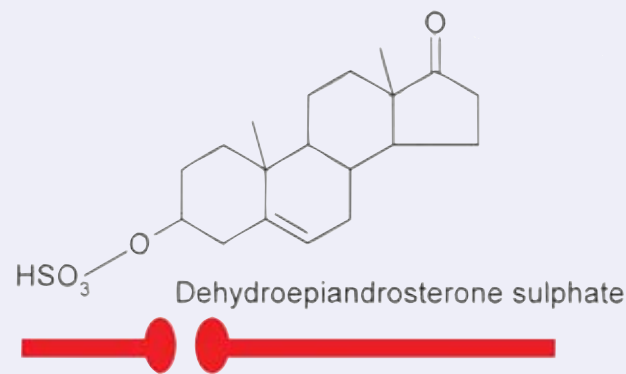<smiles>CC12CCC3C(CC=C4CC(O)CCC43C)C1CCC2=O</smiles>

Dehydroepiandrosterone<smiles>CC12CCC(O)CC1=CCC1C2CCC2(C)C(O)CCC12</smiles>

Androstenediol<smiles>CC12CCC3C(CCC4=CC(=O)CCC43C)C1CCC2=O</smiles>

Androstenedione<smiles>CC12CCC(=O)C=C1CCC1C2CCC2(C)C(O)CCC12</smiles>

Testosterone

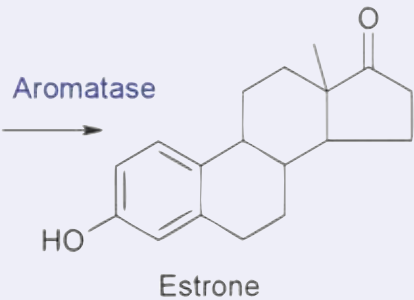<smiles>CC12CCC3c4ccc(O)cc4CCC3C1CCC2O</smiles>

Estradiol<smiles>CC(C)(C)OC(C)(C)C(C)(C)C</smiles>

Dihydrotestosterone

Fig. 2 Intracrine processing of serum dehydroepiandrosterone sulphate (DHEA-S). In the circulation the concentration of DHEA-S is more than 200 -fold higher than that of DHEA as it serves as the DHEA reservoir. DHEA-S is taken up by cells via organic anion transporter protein-B. Inside the cell it can be desulphated by steroid sulphatase, but resulphated by sulphotransferase. Free DHEA is fed into the further intracrine machinery,

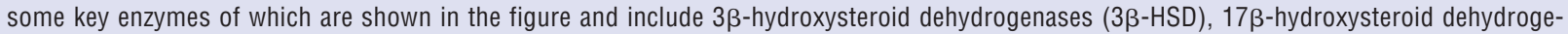
nases $(17 \beta-H S D)$, aromatase and $5 \alpha$-reductase. This intracrine machinery has been apparently fine-tuned in different cells and tissues to meet the local needs; such tailor making does not occur in murines, and these murine models cannot be therefore not be used to study intracrine processing of DHEA. 
MSCs with growth factors might enhance transfer of anti-apoptotic signal to CMCs.

\section{Genetic engineering}

Recently, genetic enhancement of MSCs has gained considerable attention. MSCs could be manipulated to secret a gene product, enhance cell survival, alter cell homing and direct cell differentiation. First brought into play for MSCs by the Dzau group, the research group genetically modified rat MSCs with phosphorylated Akt prior to intramyocardial transplantation. Down-regulation of pro-apoptotic Bax gene and activation of anti-apoptotic Bcl-2 gene resulted in $80 \%$ reduction of cell apoptosis after $24 \mathrm{hrs}$ of hypoxia. Using this strategy, they were able to report significant inhibition of cardiac remodelling processes and improved cardiac function after myocardial infarction followed by MSC transplantation [87]. They speculated that paracrine actions exerted by the cells through the release of soluble factors might be important mechanisms of tissue repair and functional improvement after injection of the Akt-MSCs [88]. Non-viral transfer of Hemoxygenase-1 gene to MSCs, providing cardioprotective properties (and by-products of heme-metabolism, as carbon monoxide, bilirubin and iron, that precede anti-inflammatory, anti-apoptotic, anti-mitogenic and vasodilator effects), resulted in a higher number of surviving MSCs for cardiac repair and regeneration [89]. Eventual additional paracrine effects were not investigated yet. Li et al. [47] investigated non-viral transfer of the anti-apoptotic Bcl-2-gene to MSCs prior to direct transplantation in a rat myocardial infarction model. This led to improved cell survival in vivo and to improved heart function [47]. Unwanted excessive and potentially harmful gene expression has to be somehow circumvented, e.g. hypoxiainducible expression has been reported for Akt, $\mathrm{HO}-1$ and $\mathrm{Bcl}-2$. Co-overexpression of Akt and Angiopoietin-1 (Ang-1), by adenoviral transduction, was found to improve cell survival together with restoration of regional blood flow [90]. Indeed extensive cell survival and myogenic differentiation were coupled with a significantly higher vessel density and smooth muscle cell covering (indicating maturation of newly formed vessels) in the study group compared to the control groups.

Another approach for gene modification aims to influence migration and homing processes. Overexpression, by retroviral transduction, of chemokine receptor 4 (CXCR4), which is the cognate receptor for SDF-1, a chemokine that is required for homing of progenitor cells to ischaemic tissues, led to an increase in the number of cells homing to ischaemic tissues after intravenous administration $24 \mathrm{hrs}$ after myocardial infarction in rat compared to non-modified, naive MSCs. Decreased anterior wall thinning, improved left ventricular function and a decrease in collagen I/III ratio were also reported [91]. A similar investigation with adenoviral transduction of CXCR4/green fluorescent protein and SDF-1 pre-treatment led to an up-regulation of matrix metalloproteinases in CXCR4 overexpressing MSCs, that might facilitate MSC engraftment in collagenous tissue of infarcted tissue, and also to a significant neoangiomyogenesis [92]. Drawbacks in gene-modification techniques are associated with limited gene size that can be carried by the virus, infections and immunological side effects caused by viral gene transfer restricting the use of this method to animal models. Low efficiency and high toxicity limit the use of non-viral gene transfer systems, even though improvement of these systems, especially concerning toxicity.

\section{Hypoxia preconditioning}

Usually optimal culture conditions including normoxia, have been used in laboratories in order to achieve high cell vitality and proliferation rates. Nonetheless MSCs derive from hypoxic tissues, e.g. hypoxic niches in bone marrow, upon transplantation to infarcted myocardial tissue they are again subjected to hypoxia. Consequently hypoxia effects have been investigated in the context of simulating the microenvironment in vivo, myocardial infarction or hind limb ischaemia models, and hypoxia exposition studies in vitro. Shortterm exposure of MSCs to HGF induces the activation of its cognate Met-receptor and downstream effectors ERK1/2, p38 MAPK and PI3K/Akt [46]. If MSCs are subjected to hypoxia in vitro the Akt signalling pathway is activated so that cell viability and cell cycle rates are maintained. Furthermore expression of c-Met is induced and c-Met signalling is enhanced, resulting in higher migration rates in response to ischaemic tissue-secreted HGF after intraarterial injection in a rat hind limb ischaemia model [93]. These data suggest a specific influence of hypoxia on MSCs that in the case of Aktactivation leads to a better survival of anoikisis, cell death by integrin detachment, which can threaten the desired outcome of the cell transplantation processes. Li et al. showed significant hypoxiainduced VEGF-overexpression and enhanced MSC survival rate under hypoxia after $\mathrm{Bcl}-2$ (B-cell lypmphoma)-gene transfer in rat MSCs in vitro. It was concluded, that there is a hypoxia-regulated, VEGF-mediated cardioprotective effect and the induction of functional collateral vessels when Bcl-2-engineered MSCs are transplanted into infarcted hearts [47]. Apart from beneficial effects on cell metabolism hypoxic preconditioning can direct cells to cardiogenic differentiation prior to transplantation [45], possibly preventing earlier reported adverse effects, such as osteogenesis [94].

\section{Pharmacological interventions}

\section{Dehydroepiandrosterone pro-hormone}

It has been well established and recently reviewed that sexual dimorphism exists in many cardiovascular, cardiopulmonary, neurodegenerative and endocrine disorders. Oestrogen stimulates growth hormone production by bone marrow MSCs and endothelial progenitor cells (EPCs), and apparently via stimulation of somatomedin C (IGF-I) influences myocardial remodelling after an ischaemic insult. Other useful effects include oestrogen-stimulated angiogenesis and oestrogen-inhibited cardiac fibrosis. It is concluded that '....a greater understanding of sex hormones on diverse stem cell populations is required to improve their ultimate clinical efficacy' [95]. 

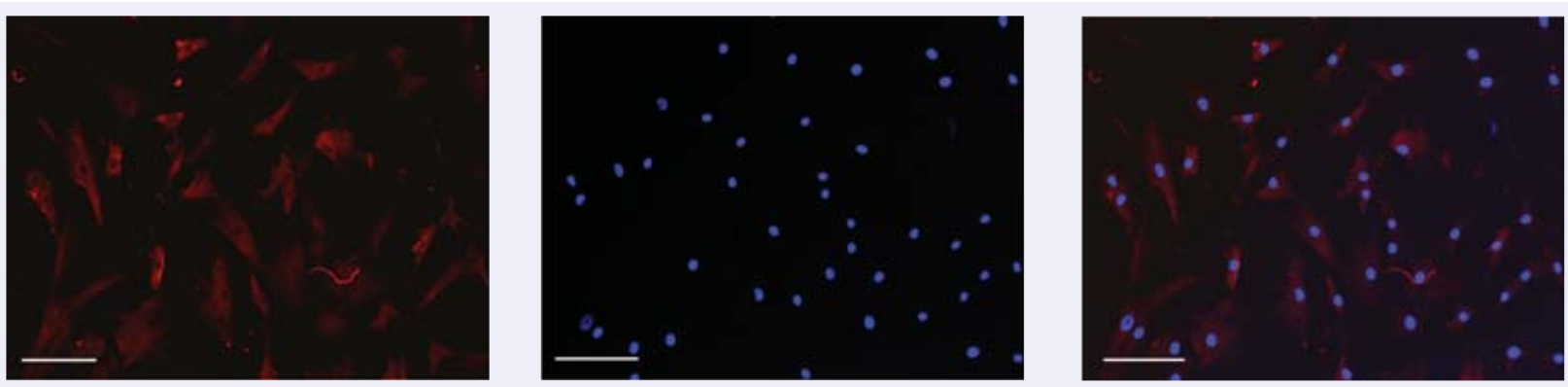

Fig. 3 Immunofluorescence staining demonstrates the presence of $5 \alpha$-reductase in human fat-derived mesenchymal stem cells (MSCs). Panel to the left shows MSCs, which are positive for $5 \alpha$-reductase (red colour). The middle panel shows DAPI nuclear stain (blue colour). The panel to the right shows the overlay. This enzyme converts DHEA-derived testosterone to dihydrotestosterone for intracellular MSC use. Bar $=100 \mu \mathrm{m}$.

Although MSCs are affected by sex steroids, little attention has been paid to two interesting facts: (1) serum DHEA levels are very high at the time of birth and rapid growth and development; (2) DHEA, normally produced in zona reticularis of the adrenal cortex is, in man and higher apes, subjected to organ-specific, intracrine conversion to active sex steroids. Organ-specific refers here to tailor making: in female breast and uterus, most of it is converted to $17 \beta$-oestradiol, whereas in male prostate most become dihydrotestosterone. It is similarly but as yet unknown way converted to active sex steroids in other organs along the intracrine pathways shown in Fig. 2.

It has been estimated that $75 \%$ of the oestrogens in premenopausal and $100 \%$ of the oestrogens in post-menopausal women derives from DHEA. Similarly, $50 \%$ of testosterone is locally produced from DHEA even in younger men [96]. Sex steroids can have important regulatory effects. It was recently shown that DHEA treatment up-regulates 5-20-fold integrin $\alpha 1$ and $\alpha 2$ subunits, which enables the intercalated duct epithelial progenitory cells in salivary glands to migrate to acinus, and to receive there a differentiation signal from The basement-membrane located laminin $\alpha 1$ [97] so that they transdifferentiate into secretory acinar cells [98].

Interestingly, oestrogens have been shown to affect mouse bone marrow MSCs, but there have been no studies on the eventual intracrine DHEA processing machinery in these cells although ongoing studies demonstrate that some such enzymes are present and some are induced by the presence of substrate in a positive feedforward feedback system (Fig. 2). Studies are ongoing on the effect of such treatment on their integrin receptor expression levels.

\section{Atorvastatin}

3-Hydroxy-3-methylglutaryl coenzyme A (HMG-CoA) reductase inhibitors, statins, represent a group of medications that are prescribed for its cholesterol-lowering effects. Furthermore so-called pleiotropic effects were ascribed to statins, such as protection of endothelial function, increased nitric oxide bioavailability, antioxidant effects and stabilization of atherosclerotic plaques [99-102]. Statins were shown to accelerate re-endothelialization and reduce dose-dependently neointimal thickening after carotid balloon injury in a rat model [103]. This effect was caused by increased numbers of circulating EPCs and induction of adhesiveness of EPC by up-regulation of integrin subunits. In a pre-clinical study pleiotropic statin effects were investigated in MSC transplantation after myocardial ischaemia/reperfusion injury to Chinese swine pre-treated with atorvastatin [104]. Improvement of efficacy was found due to atorvastatin-enhanced cell survival and differentiation into cardiomyocytes, decrease of infarcted area, promoting of angiogenesis and reversal of ventricular remodelling processes.

\section{Pre-clinical application on cardiovascular diseases}

Animal models in the field of MSC transplantation to cardiac tissue mainly address effects on heart function (e.g. in myocardial infarction, acute myocarditis) and clarification of repair and regenerative mechanisms. In focus stands the fate of transplanted MSCs, its complex interplay with the environmental tissue and organism responses, including eventually unwanted side effects.

According to the high clinical frequency of myocardial infarction small and large animal models both have been applied in a considerable number, addressing mainly the proof of functional benefits, like left ventricular ejection fraction, summarized exemplary in Table 1 (direct intramyocardial transplantation models) and pathomechanisms of MSC transplantation. Recently, Schuleri et al. [105] reported a significant gain of left ventricular function at 8 weeks in a pig model investigation of intramyocardial transplantation of MSCs. The research group showed an early improvement of resting myocardial blood flow after 1 week, which correlated positive to an increase of vessel size in the MSC group compared to control groups. These findings indicated neovascularization processes in advance to significant cardiomyogenesis, nourishing the hypothesis of paracrine secretion mediated effects [105]. Engraftment of MSCs, here defined as cell integration and trans differentiation, in no doubt plays a major role in cell transplantation processes. However, cell integration into the injected tissue 


\section{Growth Factors Pre-Treatment} FGF-2, IGF-1, BMP-2

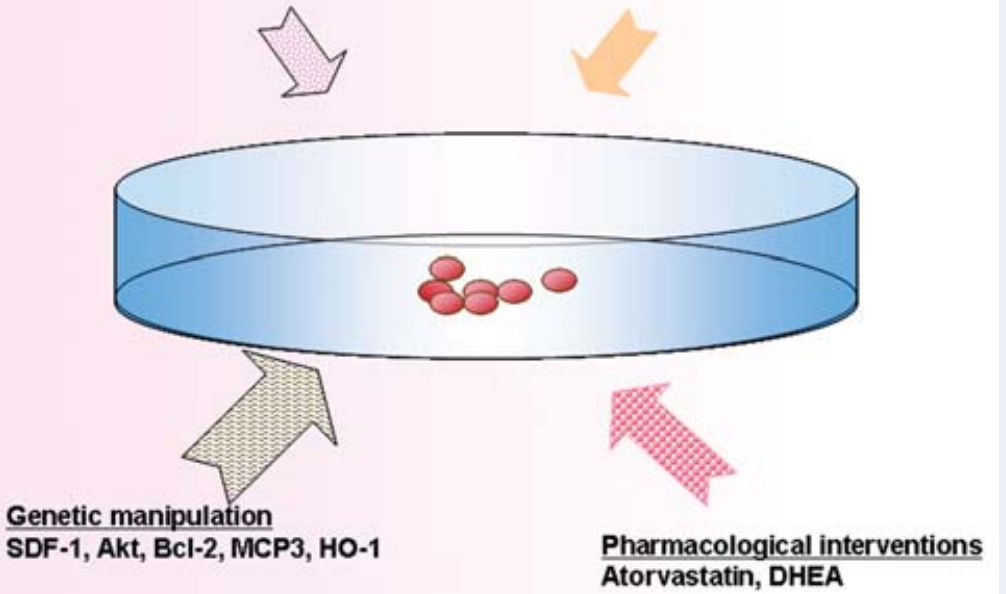

Hypoxia Preconditioning
Fig. 4 Different approaches for ex vivo MSC manipulation.

Table 1 Summary of pre-clinical studies on left ventricular function after MSC transplantation to injured heart

\begin{tabular}{|c|c|c|c|c|c|}
\hline Model & Cell number & Measurement method & Modification & Functional results & Research group \\
\hline $\begin{array}{l}\text { Pig, LAD-occlusion } \\
(60 \text { min.) and reperfusion }\end{array}$ & $\begin{array}{l}200 \times 100 \mathrm{E} 6 \\
15 \text { sites, intramy- } \\
\text { ocardial injection }\end{array}$ & MRI Imaging & No & $\begin{array}{l}\text { Significant } \uparrow \text { in LV-EF of week } 1 \text { to } \\
\text { week } 8\end{array}$ & $\begin{array}{l}\text { Schuleri et al. } \\
\text { [105] }\end{array}$ \\
\hline $\begin{array}{l}\text { Pig, permanent } \\
\text { LAD ligation }\end{array}$ & $\begin{array}{l}1 \times 10 \text { E } 6 \text {, } \\
\text { intramyocardial } \\
\text { injection }\end{array}$ & Echocardiography & $\begin{array}{l}\text { No (long- } \\
\text { term culture) }\end{array}$ & $\begin{array}{l}\text { Significant } \uparrow \text { in LV-EF at } 2 \text { and } \\
4 \text { weeks in comparison to control } \\
\text { (saline injection) }\end{array}$ & $\begin{array}{l}\text { Nakamura et al. } \\
{[106]}\end{array}$ \\
\hline $\begin{array}{l}\text { Lewis-Rat, permanent } \\
\text { LAD ligation }\end{array}$ & $\begin{array}{l}2 \times 10 \text { E } 6 \text {, five } \\
\text { injections }\end{array}$ & Catheter conductance & No & $\begin{array}{l}\text { Significant } \uparrow \text { in LV-EF in MSC } \\
\text { group compared to medium injec- } \\
\text { tion group at } 8 \text { weeks }\end{array}$ & Berry et al. [107] \\
\hline $\begin{array}{l}\text { Lewis-Rat, permanent } \\
\text { LAD ligation }\end{array}$ & $\begin{array}{l}6 \times 10 \text { E } 6 \text {, six } \\
\text { injection sites }\end{array}$ & Catheter conductance & $\mathrm{Bcl}-2$ gene & $\begin{array}{l}\text { Significant } \uparrow \text { in LV-EF in Bcl-2- } \\
\text { gene-midified group compared to } \\
\text { saline group at } 6 \text { weeks }\end{array}$ & Li et al. [47] \\
\hline Lewis-Rat & $5 \times 10 \mathrm{E} 6$ & Echocardiography & No & $\begin{array}{l}\text { Significant } \uparrow \text { in fractional } \\
\text { LV-EF in allogeneic and syngenic } \\
\text { MSC groups compared to buffer } \\
\text { goup at } 28 \text { days }\end{array}$ & $\begin{array}{l}\text { Imanishi et al., } \\
\text { [108] }\end{array}$ \\
\hline $\begin{array}{l}\text { Spontaneously hyperten- } \\
\text { sive rats, permanent } \\
\text { LAD ligation }\end{array}$ & $\begin{array}{l}1 \times 10 \text { E } 6 \text {, five } \\
\text { sites }\end{array}$ & Echocardiography & No & $\begin{array}{l}\text { Significant } \uparrow \text { in MSC group } \\
\text { compared to only medium group }\end{array}$ & $\begin{array}{l}\text { de Macedo Brada } \\
\text { et al. [109] }\end{array}$ \\
\hline $\begin{array}{l}\text { Sprague-Dawley-Rat, } \\
\text { permanent LAD ligation }\end{array}$ & $\begin{array}{l}5 \times 10 \text { E } 6 \text {, five } \\
\text { sites }\end{array}$ & Langendorff model & Akt gene & $\begin{array}{l}\text { LV-SP indistinguishable from } \\
\text { sham-operated animals at } 2 \text { weeks }\end{array}$ & Mangi et al. [87] \\
\hline
\end{tabular}

$\mathrm{LAD}=$ left anterior descending coronary artery, $\mathrm{MBP}=$ myocardial blood flow, LV-EF $=$ left ventricular ejection fraction, $\mathrm{LV}-\mathrm{SP}=$ left ventricular systolic performance and $\mathrm{Bcl}$ (B-cell lymphoma). 
actually takes place in a non-significant quantity [47]. Sporadic in vivo transdifferentiation into cardiomyocytes-like cells [106] and ECs, integrated into vessels [105] was shown, indicating once more non-structural effects of MSC apply. Findings of reduction in infarction size differ from non-significant [107] to significant [109-111]. In cardiomyopathy beneficial effects on cardiac function were reported $[112,113]$. In a rabbit model of chronic doxorubicin cardiomyopathy reduced myocardial fibrosis and increased activity of MMP-1 and MMP-2 and decreased activity of tissue inhibitors were observed [112]. Even though immunomodulative and immunosuppressive effects have been ascribed to MSCs [114] only few pre-clinical data are given for MSC therapeutic approach for myocarditis yet. Ohnishi et al. [115] reported positive effects derived from intravenous MSCs injection after induction of acute myocarditis (experimental autoimmune myocarditis) in rat. Hereby, a reduced number of CD68-positive inflammatory cells and monocyte chemoattractant protein-1 expression in myocardium together with improved cardiac function was shown [115]. In another study of EAM in rat an inhibited myocardial expression of the inflammatory cytokines interleukin-2, -6, and -10 mRNAs was found [116]. It was also suggested that MSCs are suitable to prevent chronic rejection in heart transplantation due to $\mathrm{CD}^{+}$T-cell suppression [117]. Migration of intravenously transferred MSCs to heart allograft during chronic rejection was reported [118]. However, also reports of eventual promotion of rejection were made [119]. MSC recellularization for preserving viability of bypass grafts stimulates efforts to improve therapies in cardiovascular bypass surgery. In a recent report, a vein grafting model evidence of MSC differentiation into ECs and increased reendothelialization and reduction of neointimal formation [120] after MSC transplantation was reported. Recellularization capacity of MSC was also applied to tissue-engineered heart valves [121]. Safety studies in large animals investigating dose-dependent effects have shown no relevant results so far [110]. 'Off the shelf' use of allogeneic MSCs in a swine safety study with repeated high dose injections (up to $800 \times 10^{6} \mathrm{MSC}$ ) into the heart revealed no side effects in regard to sustained ventricular arrhythmia, anaphylaxis or significant cardiac enzyme release, and long-term histopathology results were unobtrusive with regard to rejection, calcification, teratoma and myocardial infarction [122]. Taken together, promising strategies have been established to apply MSCs with their great profile for not only myocardial infarction but also other cardiac diseases though leaving yet many questions open to answer in future research.

\section{Clinical application: where are we?}

Since 2002, numerous clinical trials have been performed to test the safety and efficacy of bone-marrow-derived mononuclear cells (MNC) transplantation for the treatment of myocardium infarction [123]. Although most of these studies were not double-blinded or randomly designed, the initial results confirmed the safety of such a cell therapy and thereby aroused the enthusiasm to attempt MSC transplantation. However, compared with MNC and other bonemarrow-derived progenitor cells [124], which were isolated or sorted directly from fresh whole bone marrow, MSCs usually need some time in a cell culture to allow their cell purification and expansion so that adequate numbers can be achieved prior to transplantation. The microbial contamination during cell culture could cause a failure of the cell preparation and the xenogeneic serum additions in the culture media could cause unexpected alteration of human MSCs and subsequent host immune rejection. Therefore, there is a need for an animal serum-free replacement in the clinical scale propagation of human MSCs [125]. Secondly, the mean diameter of cultured MSCs in the injection suspension was $20 \mu \mathrm{m}$, which was much larger than MNC (mean diameter 10-12 $\mu \mathrm{m}$ ), and hence a direct intracoronary infusion of MSCs might result in iatrogenic coronary embolisms and microinfarctions [126]. Considering the above facts, unlike its MNC counterparts, the clinical application of MSCs for cardiac repair is still in its initial stages and only a few small phase I-II clinical studies have been reported.

In 2004, a cardiologists group from China firstly infused autologous MSCs intracoronarily in patients with acute myocardial infarction [127]. In Chen's study, MSCs were cultured for 10 days and eventually 5-6 $\times 10^{9}$ MSCs were obtained and infused through the targeted coronary artery after a successful percutaneous coronary intervention. Serial cardiac echocardiographic and positron emission tomographic monitoring demonstrated improvement of cardiac function 3 months after cell transplantation. However, no further information was presented to clarify the culture process and eventual myocardial injuries after intracoronary cell infusion.

In another study from Greece, MSCs were in vitro cultured for 7 days with $10 \%$ foetal calf serum under good laboratory practice conditions, and then $1-2 \times 10^{6}$ cells were infused through a stented coronary artery [128]. Before cell transplantation, the cell samples were analysed and $66 \% \pm 19 \%$ of the cells in culture were positive for the biomarkers of MSCs. Furthermore, the authors selected into their series five patients who had implantable cardioverter defibrillator (ICD) to investigate the possible proarrhythmic potential of MSC treatment [129]. At 16-36 months follow-up, interrogation of the ICD failed to detect sustained or non-sustained ventricular arrhythmia in any of the MSCs treated patient. Therefore, the authors concluded that MSC transplantation did not appear to have any arrythmogenic potential in this small series.

The preliminary results of first clinical trial of MSC transplantation for cardiac repair in United States were reported recently at the American College of Cardiology's Innovation in Intervention: i2 Summit [130]. In the 53-year-old patient, double-blind, placebocontrolled study, the allogeneic MSCs were taken from young healthy volunteers and intravenously injected like i.v. drugs. During the 6-month follow-up, the heart and lung function improved significantly and arrhythmic events were four times less frequent than in the placebo group. The investigators reported that such allogeneic cell products did not need time-consuming cell manipulations just prior to the treatment, but they are readily available to satisfy the needs of clinical community. 
In the above-mentioned US study, MSCs were administrated through a standard intravenous route. Although this route is much more convenient for the patients than the intra-arterial coronary route, pilot animal studies have demonstrated that intravenous route is much less site specific and lead to much more extensive systemic engraftment than other more targeted delivery approaches [131]. It is generally accepted that even after intracoronary infusion only $1-3 \%$ of delivered cells actually engraft within the infarcted zone [132]. Since the end of 2007, the National Heart, Lung and Blood Institute initiated another multicentre study to inject high- or low-dosage MSC preparations directly into the damaged myocardium that did not receive a bypass graft during open-chest coronary bypass procedure [133]. Although the cardiac surgeons can identify the myocardial scar and thus choose appropriate injection sites, the locally injected cells still tend to migrate to extracardiac organs, especially to the spleen [134]. In the future clinical studies, the comparison of various delivery routes and methods to improve the local cardiac retention of the cells should be addressed.

Recently, a series of randomly designed clinical studies confirmed the safety and feasibility of MNC transplantation; however, they also showed that such un-cultured or non-sorted cell preparations did not have any effects on or only slightly improved heart function [135]. MSCs currently emerge as a promising cell resource in clinical application to repair the damaged heart. According to the registered data from www.clinicaltrials.gov, a web-based service of National Institute of Health of United States, there are three ongoing phase I-II trials using MSCs for cardiac applications and totally around 140 patients with myocardial infarction have been recruited across Europe and United States for these studies [136]. Compared with freshly isolated MNCs, MSCs are easy to label for the subsequent in vivo tracking using magnetic resonance imaging and other imaging techniques [137]. Furthermore, the time period used for cell culture offers a platform for MSC-targeted gene therapy. MSCs can be engineered with various target genes to augment angiogenesis, inhibit apoptosis and reverse myocardial remodelling $[47,53]$.

\section{Acknowledgements}

This work was supported by the German Helmholtz Association, Mecklenburg-Vorpommern (Nachwuchsgruppe Regenerative Medizin Regulation der Stammzellmigration 0402710), German Research Foundation, SFB/Transregio 37 and BMBF START-MSC.

\section{References}

1. Pittenger MF, Mackay AM, Beck SC, Jaiswal RK, Douglas R, Mosca JD, Moorman MA, Simonetti DW, Craig S, Marshak DR. Multilineage potential of adult human mesenchymal stem cells. Science. 1999; 284: 143-7.

2. Dormady SP, Bashayan 0, Dougherty R, Zhang XM, Basch RS. Immortalized multipotential mesenchymal cells and the hematopoietic microenvironment. J Hematother Stem Cell Res. 2001; 10: 125-40.

3. Dominici M, Le Blanc K, Mueller I, Slaper-Cortenbach I, Marini F, Krause D, Deans R, Keating A, Prockop D, Horwitz E. Minimal criteria for defining multipotent mesenchymal stromal cells. The International Society for Cellular Therapy position statement. Cytotherapy. 2006; 8: 315-317.

4. Docheva D, Padula D, Popov C, Mutschler W, Clausen-Schaumann H, Schieker M. Researching into the cellular shape, volume and elasticity of mesenchymal stem cells, osteoblasts and osteosarcoma cells by atomic force microscopy. $J$ Cell Mol Med. 2008; 12: 537-52.

5. Ho AD, Wagner W, Franke W. Heterogeneity of mesenchymal stromal cell preparations. Cytotherapy. 2008; 10: $320-30$.
6. Horwitz EM, Keating A. Nonhematopoietic mesenchymal stem cells: what are they? Cytotherapy. 2000; 2: 387-8.

7. Horwitz EM, Le Blanc K, Dominici M, Mueller I, Slaper-Cortenbach I, Marini FC, Deans RJ, Krause DS, Keating A. Clarification of the nomenclature for MSC: The International Society for Cellular Therapy position statement. Cytotherapy. 2005; 7: 393-5.

8. Wagner W, Ho AD. Mesenchymal stem cell preparations-comparing apples and oranges. Stem Cell Rev. 2007; 3: 239-48.

9. Friedenstein AJ, Piatetzky S, II, Petrakova KV. Osteogenesis in transplants of bone marrow cells. J Embryol Exp Morphol. 1966; 16: 381-90.

10. Zuk PA, Zhu M, Mizuno H, Huang J, Futrell JW, Katz AJ, Benhaim P, Lorenz HP, Hedrick MH. Multilineage cells from human adipose tissue: implications for cell-based therapies. Tissue Eng. 2001; 7 : 211-28.

11. Bieback K, Kern S, Kluter H, Eichler H. Critical parameters for the isolation of mesenchymal stem cells from umbilical cord blood. Stem Cells. 2004; 22: 625-34.

12. Kuznetsov SA, Mankani MH, Gronthos S, Satomura K, Bianco P, Robey PG. Circulating skeletal stem cells. J Cell Biol. 2001; 153: 1133-40.
13. Jiang $Y$, Vaessen B, Lenvik T, Blackstad M, Reyes M, Verfaillie CM. Multipotent progenitor cells can be isolated from postnatal murine bone marrow, muscle, and brain. Exp Hematol. 2002; 30: 896-904.

14. Beltrami AP, Cesselli D, Bergamin N, Marcon P, Rigo S, Puppato E, D'Aurizio F, Verardo R, Piazza S, Pignatelli A, Poz A, Baccarani U, Damiani D, Fanin R, Mariuzzi L, Finato N, Masolini P, Burelli S, Belluzzi O, Schneider C, Beltrami CA. Multipotent cells can be generated in vitro from several adult human organs (heart, liver, and bone marrow). Blood. 2007; 110: 3438-46.

15. da Silva Meirelles L, Chagastelles PC, Nardi NB. Mesenchymal stem cells reside in virtually all post-natal organs and tissues. J Cell Sci. 2006; 119: 2204-13.

16. Bianco P, Robey PG, Simmons PJ. Mesenchymal stem cells: revisiting history, concepts, and assays. Cell Stem Cell. 2008; 2: 313-19.

17. da Silva Meirelles L, Caplan AI, Nardi NB. In search of the in vivo identity of mesenchymal stem cells. Stem Cells. 2008; 26: 2287-99.

18. Kern S, Eichler H, Stoeve J, Kluter H, Bieback K. Comparative analysis of mesenchymal stem cells from bone marrow, 
umbilical cord blood, or adipose tissue. Stem Cells. 2006; 24: 1294-301.

19. Wagner W, Roderburg C, Wein F, DiehImann A, Frankhauser M, Schubert R, Eckstein V, Ho AD. Molecular and secretory profiles of human mesenchymal stromal cells and their abilities to maintain primitive hematopoietic progenitors. Stem Cells. 2007; 25: 2638-47.

20. Wagner W, Wein F, Seckinger A, Frankhauser M, Wirkner U, Krause U, Blake J, Schwager C, Eckstein V, Ansorge W, Ho AD. Comparative characteristics of mesenchymal stem cells from human bone marrow, adipose tissue, and umbilical cord blood. Exp Hematol. 2005; 33: 1402-16.

21. Wagner W, Feldmann RE Jr, Seckinger A, Maurer MH, Wein F, Blake J, Krause U, Kalenka A, Burgers HF, Saffrich R, Wuchter P, Kuschinsky W, Ho AD. The heterogeneity of human mesenchymal stem cell preparations-evidence from simultaneous analysis of proteomes and transcriptomes. Exp Hematol. 2006; 34: 536-48.

22. Jiang $\mathrm{Y}$, Jahagirdar BN, Reinhardt RL, Schwartz RE, Keene CD, Ortiz-Gonzalez XR, Reyes M, Lenvik T, Lund T, Blackstad M, Du J, Aldrich S, Lisberg A, Low WC, Largaespada DA, Verfaillie CM. Pluripotency of mesenchymal stem cells derived from adult marrow. Nature. 2002; 418: 41-9.

23. Kogler G, Sensken S, Airey JA, Trapp T, Muschen M, Feldhahn N, Liedtke S, Sorg RV, Fischer J, Rosenbaum C, Greschat S, Knipper A, Bender J, Degistirici 0, Gao J, Caplan AI, Colletti EJ, Almeida-Porada G, Muller HW, Zanjani E, Wernet P. A new human somatic stem cell from placental cord blood with intrinsic pluripotent differentiation potential. J Exp Med. 2004; 200: 123-35.

24. Kucia M, Wysoczynski M, Ratajczak J, Ratajczak MZ. Identification of very small embryonic like (VSEL) stem cells in bone marrow. Cell Tissue Res. 2008; 331: 125-34.

25. Simmons PJ, Torok-Storb B. Identification of stromal cell precursors in human bone marrow by a novel monoclonal antibody, STR0-1. Blood. 1991; 78: 55-62.

26. Quirici N, Soligo D, Bossolasco P, Servida F, Lumini C, Deliliers GL. Isolation of bone marrow mesenchymal stem cells by anti-nerve growth factor receptor antibodies. Exp Hematol. 2002; 30: 783-91.

27. Sabatini F, Petecchia L, Tavian M, Jodon de Villeroche V, Rossi GA, Brouty-Boye
D. Human bronchial fibroblasts exhibit a mesenchymal stem cell phenotype and multilineage differentiating potentialities. Lab Invest. 2005; 85: 962-71.

28. Bearzi C, Rota M, Hosoda T, Tillmanns J, Nascimbene A, De Angelis A, YasuzawaAmano S, Trofimova I, Siggins RW, Lecapitaine N, Cascapera S, Beltrami AP, D’Alessandro DA, Zias E, Quaini F, Urbanek K, Michler RE, Bolli R, Kajstura J, Leri A, Anversa P. Human cardiac stem cells. Proc Natl Acad Sci USA. 2007; 104: 14068-73.

29. Limana F, Zacheo A, Mocini D, Mangoni A, Borsellino G, Diamantini A, De Mori R, Battistini L, Vigna E, Santini M, Loiaconi V, Pompilio G, Germani A, Capogrossi MC. Identification of myocardial and vascular precursor cells in human and mouse epicardium. Circ Res. 2007; 101: 1255-65.

30. Hinescu ME, Gherghiceanu M, Mandache E, Ciontea SM, Popescu LM. Interstitial Cajal-like cells (ICLC) in atrial myocardium: ultrastructural and immunohistochemical characterization. J Cell Mol Med. 2006; 10: 243-57.

31. Hinescu ME, Popescu LM. Interstitial Cajal-like cells (ICLC) in human atrial myocardium. J Cell Mol Med. 2005; 9: 972-5.

32. Popescu LM, Gherghiceanu M, Hinescu ME, Cretoiu D, Ceafalan L, Regalia T, Popescu AC, Ardeleanu C, Mandache E. Insights into the interstitium of ventricular myocardium: interstitial Cajal-like cells (ICLC). J Cell Mol Med. 2006; 10: 429-58.

33. Faussone-Pellegrini MS. Interstitial cells of Cajal: once negligible players, now blazing protagonists. Ital J Anat Embryol. 2005; 110: 11-31.

34. Faussone-Pellegrini MS, Thuneberg L. Guide to the identification of interstitial cells of Cajal. Microsc Res Tech. 1999; 47: 248-66.

35. Huizinga JD, Faussone-Pellegrini MS. About the presence of interstitial cells of Cajal outside the musculature of the gastrointestinal tract. J Cell Mol Med. 2005; 9: 468-73.

36. Popescu LM, Ciontea SM, Cretoiu D. Interstitial Cajal-like cells in human uterus and fallopian tube. Ann N Y Acad Sci. 2007; 1101: 139-65.

37. Popescu LM, Hinescu ME, Ionescu N, Ciontea SM, Cretoiu D, Ardelean C. Interstitial cells of Cajal in pancreas. $J$ Cell Mol Med. 2005; 9: 169-90.

38. Bobryshev YV. Subset of cells immunopositive for neurokinin-1 receptor identified as arterial interstitial cells of
Cajal in human large arteries. Cell Tissue Res. 2005; 321: 45-5.

39. Pucovsky V, Harhun MI, Povstyan OV, Gordienko DV, Moss RF, Bolton TB. Close relation of arterial ICC-like cells to the contractile phenotype of vascular smooth muscle cell. J Cell Mol Med. 2007: 11; 764-75.

40. Mandache E, Popescu LM, Gherghiceanu M. Myocardial interstitial Cajal-like cells (ICLC) and their nanostructural relationships with intercalated discs: shed vesicles as intermediates. J Cell Mol Med. 2007; 11: 1175-84.

41. Phinney DG, Prockop DJ. Concise review: mesenchymal stem/multipotent stromal cells: the state of transdifferentiation and modes of tissue repair-current views. Stem Cells. 2007; 25: 2896-902.

42. Makino S, Fukuda K, Miyoshi S, Konishi F, Kodama H, Pan J, Sano M, Takahashi $\mathrm{T}$, Hori S, Abe H, Hata J, Umezawa A, Ogawa $\mathbf{S}$. Cardiomyocytes can be generated from marrow stromal cells in vitro. $J$ Clin Invest. 1999; 103: 697-705.

43. Toma C, Pittenger MF, Cahill KS, Byrne BJ, Kessler PD. Human mesenchymal stem cells differentiate to a cardiomyocyte phenotype in the adult murine heart. Circulation. 2002; 105: 93-8.

44. Yoon J, Min BG, Kim YH, Shim WJ, Ro YM, Lim DS. Differentiation, engraftment and functional effects of pre-treated mesenchymal stem cells in a rat myocardial infarct model. Acta Cardiol. 2005; 60: 277-84.

45. Xie XJ, Wang JA, Cao J, Zhang X. Differentiation of bone marrow mesenchymal stem cells induced by myocardial medium under hypoxic conditions. Acta Pharmacol Sin. 2006; 27: 1153-8.

46. Forte G, Minieri M, Cossa P, Antenucci D, Sala M, Gnocchi V, Fiaccavento $R$, Carotenuto F, De Vito P, Baldini PM, Prat M, Di Nardo P. Hepatocyte growth factor effects on mesenchymal stem cells: proliferation, migration, and differentiation. Stem Cells. 2006; 24: 23-33.

47. Li W, Ma N, Ong LL, Nesselmann C, Klopsch C, Ladilov Y, Furlani D, Piechaczek C, Moebius JM, Lutzow K, Lendlein A, Stamm C, Li RK, Steinhoff G. $\mathrm{BCl}-2$ engineered MSCs inhibited apoptosis and improved heart function. Stem Cells. 2007; 25: 2118-27.

48. Martin-Rendon E, Sweeney D, Lu F, Girdlestone J, Navarrete C, Watt SM. 5Azacytidine-treated human mesenchymal stem/progenitor cells derived from umbilical cord, cord blood and bone marrow do 
not generate cardiomyocytes in vitro at high frequencies. Vox Sang. 2008; 95: 137-48.

49. Verfaillie CM. Multipotent adult progenitor cells: an update. Novartis Found Symp. 2005; 265: 55-61.

50. Mezey E, Chandross KJ, Harta G, Maki RA, McKercher SR. Turning blood into brain: cells bearing neuronal antigens generated in vivo from bone marrow. Science. 2000; 290: 1779-82.

51. Ying QL, Nichols J, Evans EP, Smith AG. Changing potency by spontaneous fusion. Nature. 2002; 416: 545-8.

52. Zeng L, Rahrmann E, Hu Q, Lund T, Sandquist L, Felten M, O'Brien TD, Zhang J, Verfaillie C. Multipotent adult progenitor cells from swine bone marrow. Stem Cells. 2006; 24: 2355-66.

53. Pittenger MF, Martin BJ. Mesenchymal stem cells and their potential as cardiac therapeutics. Circ Res. 2004; 95: 9-20.

54. Aggarwal S, Pittenger MF. Human mesenchymal stem cells modulate allogeneic immune cell responses. Blood. 2005; 105: 1815-22.

55. Le Blanc $\mathbf{K}$, Ringden $\mathbf{0}$. Immunomodulation by mesenchymal stem cells and clinical experience. J Intern Med. 2007; 262: 509-25.

56. Carosella ED, Favier B, Rouas-Freiss N, Moreau P, Lemaoult J. Beyond the increasing complexity of the immunomodulatory HLA-G molecule. Blood. 2008; 111: 4862-70.

57. Au P, Tam J, Fukumura D, Jain RK. Bone marrow-derived mesenchymal stem cells facilitate engineering of long-lasting functional vasculature. Blood. 2008; 111: 4551-8.

58. Ball SG, Shuttleworth CA, Kielty CM. Mesenchymal stem cells and neovascularization: role of platelet-derived growth factor receptors. J Cell Mol Med. 2007; 11: 1012-30.

59. Tang J, Xie Q, Pan G, Wang J, Wang M. Mesenchymal stem cells participate in angiogenesis and improve heart function in rat model of myocardial ischemia with reperfusion. Eur J Cardiothorac Surg. 2006; 30: 353-61.

60. Al-Khaldi A, Eliopoulos N, Martineau D, Lejeune L, Lachapelle K, Galipeau J. Postnatal bone marrow stromal cells elicit a potent VEGF-dependent neoangiogenic response in vivo. Gene Ther. 2003; 10: 621-9.

61. Asahara T, Bauters C, Zheng LP, Takeshita S, Bunting S, Ferrara N, Symes JF, Isner JM. Synergistic effect of vascular endothelial growth factor and basic fibroblast growth factor on angiogenesis in vivo. Circulation. 1995; 92: 365-71.

62. Pasquinelli G, Tazzari PL, Vaselli C, Foroni L, Buzzi M, Storci G, Alviano F, Ricci F, Bonafe M, Orrico C, Bagnara GP, Stella A, Conte R. Thoracic aortas from multiorgan donors are suitable for obtaining resident angiogenic mesenchymal stromal cells. Stem Cells. 2007; 25: 1627-34.

63. Choong CS, Hutmacher DW, Triffitt JT. Co-culture of bone marrow fibroblasts and endothelial cells on modified polycaprolactone substrates for enhanced potentials in bone tissue engineering. Tissue Eng. 2006; 12: 2521-31.

64. Meury T, Verrier S, Alini M. Human endothelial cells inhibit BMSC differentiation into mature osteoblasts in vitro by interfering with osterix expression. J Cell Biochem. 2006; 98: 992-1006.

65. Villars F, Guillotin B, Amedee T, Dutoya S, Bordenave L, Bareille R, Amedee J. Effect of HUVEC on human osteoprogenitor cell differentiation needs heterotypic gap junction communication. $A m \mathrm{~J}$ Physiol Cell Physiol. 2002; 282: 775-85.

66. Gruber R, Kandler B, Holzmann $\mathbf{P}$, Vogele-Kadletz M, Losert U, Fischer MB, Watzek G. Bone marrow stromal cells can provide a local environment that favors migration and formation of tubular structures of endothelial cells. Tissue Eng. 2005; 11: 896-903.

67. Kaigler D, Krebsbach PH, Polverini PJ, Mooney DJ. Role of vascular endothelial growth factor in bone marrow stromal cell modulation of endothelial cells. Tissue Eng. 2003; 9: 95-103.

68. Mayer H, Bertram H, Lindenmaier W, Korff T, Weber H, Weich H. Vascular endothelial growth factor (VEGF-A) expression in human mesenchymal stem cells: autocrine and paracrine role on osteoblastic and endothelial differentiation. J Cell Biochem. 2005; 95: 827-39.

69. Ahlborg HG, Johnell $\mathbf{0}$, Turner $\mathbf{C H}$, Rannevik G, Karlsson MK. Bone loss and bone size after menopause. N Engl J Med. 2003; 349: 327-34

70. Beyth S, Borovsky Z, Mevorach D, Liebergall M, Gazit Z, Aslan H, Galun E, Rachmilewitz J. Human mesenchymal stem cells alter antigen-presenting cell maturation and induce T-cell unresponsiveness. Blood. 2005; 105: 2214-9.

71. Docheva D, Popov C, Mutschler W, Schieker M. Human mesenchymal stem cells in contact with their environment: surface characteristics and the integrin system. J Cell Mol Med. 2007; 11: 21-38.

72. Samarel AM. Costameres, focal adhesions, and cardiomyocyte mechanotransduction. Am J Physiol Heart Circ Physiol. 2005; 289: 2291-301.

73. Shai SY, Harpf AE, Babbitt CJ, Jordan MC, Fishbein MC, Chen J, Omura M, Leil TA, Becker KD, Jiang M, Smith DJ, Cherry SR, Loftus JC, Ross RS. Cardiac myocytespecific excision of the beta1 integrin gene results in myocardial fibrosis and cardiac failure. Circ Res. 2002; 90: 458-64.

74. Terracio L, Rubin K, Gullberg D, Balog E, Carver W, Jyring R, Borg TK. Expression of collagen binding integrins during cardiac development and hypertrophy. Circ Res. 1991; 68: 734-44.

75. Babbitt CJ, Shai SY, Harpf AE, Pham CG, Ross RS. Modulation of integrins and integrin signaling molecules in the pressureloaded murine ventricle. Histochem Cell Biol. 2002; 118: 431-9.

76. Liew CC, Dzau VJ. Molecular genetics and genomics of heart failure. Nat Rev Genet. 2004; 5: 811-25.

77. Ruster B, Gottig S, Ludwig RJ, Bistrian R, Muller S, Seifried E, Gille J, Henschler R. Mesenchymal stem cells display coordinated rolling and adhesion behavior on endothelial cells. Blood. 2006; 108: 3938-44.

78. Fox JM, Chamberlain G, Ashton BA, Middleton J. Recent advances into the understanding of mesenchymal stem cell trafficking. $\mathrm{Br} J$ Haematol. 2007; 137: 491-502.

79. Koivunen E, Arap W, Valtanen H, Rainisalo A, Medina OP, Heikkila P, Kantor C, Gahmberg CG, Salo T, Konttinen YT, Sorsa T, Ruoslahti E, Pasqualini R. Tumor targeting with a selective gelatinase inhibitor. Nat Biotechnol. 1999; 17: 768-74.

80. Arap W, Kolonin MG, Trepel M, Lahdenranta J, Cardo-Vila M, Giordano RJ, Mintz PJ, Ardelt PU, Yao VJ, Vidal CI, Chen L, Flamm A, Valtanen $H$, Weavind LM, Hicks ME, Pollock RE, Botz GH, Bucana CD, Koivunen E, Cahill D, Troncoso P, Baggerly KA, Pentz RD, Do KA, Logothetis CJ, Pasqualini R. Steps toward mapping the human vasculature by phage display. Nat Med. 2002; 8: 121-7.

81. Zhang M, Methot D, Poppa V, Fujio Y, Walsh K, Murry CE. Cardiomyocyte grafting for cardiac repair: graft cell death and anti-death strategies. J Mol Cell Cardiol. 2001; 33: 907-21.

82. Ghosh-Choudhury N, Abboud SL, Mahimainathan L, Chandrasekar B, 
Choudhury GG. Phosphatidylinositol 3kinase regulates bone morphogenetic protein-2 (BMP-2)-induced myocyte enhancer factor 2A-dependent transcription of BMP2 gene in cardiomyocyte precursor cells. $J$ Biol Chem. 2003; 278: 21998-2005.

83. Kofidis T, de Bruin JL, Yamane T, Balsam LB, LebI DR, Swijnenburg RJ, Tanaka M, Weissman IL, Robbins RC. Insulin-like growth factor promotes engraftment, differentiation, and functional improvement after transfer of embryonic stem cells for myocardial restoration. Stem Cells. 2004; 22: $1239-45$.

84. Rosenblatt-Velin N, Lepore MG, Cartoni C, Beermann F, Pedrazzini T. FGF-2 controls the differentiation of resident cardiac precursors into functional cardiomyocytes. J Clin Invest. 2005; 115: 1724-33.

85. Schultheiss TM, Burch JB, Lassar AB. A role for bone morphogenetic proteins in the induction of cardiac myogenesis. Genes Dev. 1997; 11: 451-62.

86. Aberg ND, Blomstrand F, Aberg MA, Bjorklund U, Carlsson B, CarlssonSkwirut C, Bang P, Ronnback L, Eriksson PS. Insulin-like growth factor-I increases astrocyte intercellular gap junctional communication and connexin43 expression in vitro. J Neurosci Res. 2003; 74: 12-22.

87. Mangi AA, Noiseux N, Kong D, He H, Rezvani M, Ingwall JS, Dzau VJ. Mesenchymal stem cells modified with Akt prevent remodeling and restore performance of infarcted hearts. Nat Med. 2003; 9: 1195-201.

88. Gnecchi M, He H, Liang OD, Melo LG, Morello F, Mu H, Noiseux N, Zhang L, Pratt RE, Ingwall JS, Dzau VJ. Paracrine action accounts for marked protection of ischemic heart by Akt-modified mesenchymal stem cells. Nat Med. 2005; 11: 367-8.

89. Tang YL, Tang Y, Zhang YC, Qian K, Shen L, Phillips MI. Improved graft mesenchymal stem cell survival in ischemic heart with a hypoxia-regulated heme oxygenase1 vector. J Am Coll Cardiol. 2005; 46: 1339-50.

90. Shujia J, Haider HK, Idris NM, Lu G, Ashraf M. Stable therapeutic effects of mesenchymal stem cell-based multiple gene delivery for cardiac repair. Cardiovasc Res. 2008; 77: 525-33.

91. Cheng Z, Ou L, Zhou X, Li F, Jia X, Zhang Y, Liu X, Li Y, Ward CA, Melo LG, Kong D. Targeted migration of mesenchymal stem cells modified with CXCR4 gene to infarcted myocardium improves cardiac performance. Mol Ther. 2008; 16: 571-9.
92. Zhang D, Fan GC, Zhou X, Zhao T, Pasha Z, Xu M, Zhu Y, Ashraf M, Wang Y. Overexpression of CXCR4 on mesenchymal stem cells augments myoangiogenesis in the infarcted myocardium. I Mol Cell Cardiol. 2008; 44: 281-92.

93. Rosova I, Dao M, Capoccia B, Link D, Nolta JA. Hypoxic preconditioning results in increased motility and improved therapeutic potential of human mesenchymal stem cells. Stem Cells. 2008; 26: 2173-82.

94. Breitbach M, Bostani T, Roell W, Xia Y, Dewald 0, Nygren JM, Fries JW, Tiemann K, Bohlen H, Hescheler J, Welz A, Bloch W, Jacobsen SE, Fleischmann BK. Potential risks of bone marrow cell transplantation into infarcted hearts. Blood. 2007; 110: 1362-9.

95. Ray R, Novotny NM, Crisostomo PR, Lahm T, Abarbanell A, Meldrum DR. Sex steroids and stem cell function. Mol Med. 2008; 14: 493-501.

96. Labrie F, Belanger A, Simard J, Van L-T, Labrie C. DHEA and peripheral androgen and estrogen formation: intracinology. Ann N Y Acad Sci. 1995; 774: 16-28.

97. Laine M, Virtanen I, Salo T, Konttinen YT. Segment-specific but pathologic laminin isoform profiles in human labial salivary glands of patients with Sjogren's syndrome. Arthritis Rheum. 2004; 50: 3968-73.

98. Laine M, Porola P, Udby L, Kjeldsen L, Cowland JB, Borregaard N, Hietanen J, Stahle M, Pihakari A, Konttinen YT. Low salivary dehydroepiandrosterone and androgen-regulated cysteine-rich secretory protein 3 levels in Sjogren's syndrome. Arthritis Rheum. 2007; 56: 2575-84.

99. Crisby M, Nordin-Fredriksson G, Shah PK, Yano J, Zhu J, Nilsson J. Pravastatin treatment increases collagen content and decreases lipid content, inflammation, metalloproteinases, and cell death in human carotid plaques: implications for plaque stabilization. Circulation. 2001; 103: 926-33.

100. Dimmeler S, Aicher A, Vasa M, MildnerRihm C, Adler K, Tiemann M, Rutten H, Fichtlscherer S, Martin H, Zeiher AM. HMG-CoA reductase inhibitors (statins) increase endothelial progenitor cells via the PI 3-kinase/Akt pathway. J Clin Invest. 2001; 108: 391-7.

101. Kwak B, Mulhaupt F, Myit S, Mach F. Statins as a newly recognized type of immunomodulator. Nat Med. 2000; 6: 1399-1402.

102. Tziakas DN, Chalikias GK, Parissis JT, Hatzinikolaou El, Papadopoulos ED,
Tripsiannis GA, Papadopoulou EG, Tentes IK, Karas SM, Chatseras DI. Serum profiles of matrix metalloproteinases and their tissue inhibitor in patients with acute coronary syndromes. The effects of short-term atorvastatin administration. Int $\mathrm{J}$ Cardiol. 2004; 94: 269-77.

103. Walter DH, Rittig K, Bahlmann FH, Kirchmair R, Silver M, Murayama T, Nishimura H, Losordo DW, Asahara T, Isner JM. Statin therapy accelerates reendothelialization: a novel effect involving mobilization and incorporation of bone marrow-derived endothelial progenitor cells. Circulation. 2002; 105: 3017-24.

104. Yang YJ, Qian HY, Huang J, Geng YJ, Gao RL, Dou KF, Yang GS, Li JJ, Shen R, He ZX, Lu MJ, Zhao SH. Atorvastatin treatment improves survival and effects of implanted mesenchymal stem cells in post-infarct swine hearts. Eur Heart $\mathrm{J}$. 2008; 29: 1578-90.

105. Schuleri KH, Amado LC, Boyle AJ, Centola M, Saliaris AP, Gutman MR, Hatzistergos KE, Oskouei BN, Zimmet JM, Young RG, Heldman AW, Lardo AC, Hare JM. Early improvement in cardiac tissue perfusion due to mesenchymal stem cells. Am J Physiol Heart Circ Physiol. 2008; 294: 2002-11

106. Nakamura Y, Wang X, Xu C, Asakura A, Yoshiyama M, From AH, Zhang J. Xenotransplantation of long-term-cultured swine bone marrow-derived mesenchymal stem cells. Stem Cells. 2007; 25: 612-20.

107. Berry MF, Engler AJ, Woo YJ, Pirolli TJ, Bish LT, Jayasankar V, Morine KJ, Gardner TJ, Discher DE, Sweeney HL. Mesenchymal stem cell injection after myocardial infarction improves myocardial compliance. Am J Physiol Heart Circ Physiol. 2006; 290: 2196-203.

108. Imanishi Y, Saito A, Komoda H, KitagawaSakakida S, Miyagawa S, Kondoh H, Ichikawa H, Sawa Y. Allogenic mesenchymal stem cell transplantation has a therapeutic effect in acute myocardial infarction in rats. J Mol Cell Cardiol. 2008; 44: 662-71.

109. de Macedo Braga LM, Lacchini S, Schaan BD, Rodrigues B, Rosa K, De Angelis K, Borges LF, Irigoyen MC, Nardi NB. In situ delivery of bone marrow cells and mesenchymal stem cells improves cardiovascular function in hypertensive rats submitted to myocardial infarction. $J$ Biomed Sci. 2008; 15: 365-74.

110. Hashemi SM, Ghods S, Kolodgie FD, Parcham-Azad K, Keane M, Hamamdzic D, Young R, Rippy MK, Virmani R, Litt H, Wilensky RL. A placebo controlled, 
dose-ranging, safety study of allogenic mesenchymal stem cells injected by endomyocardial delivery after an acute myocardial infarction. Eur Heart J. 2008; 29: 251-9.

111. Jaquet K, Krause KT, Denschel J, Faessler P, Nauerz M, Geidel S, Boczor S, Lange C, Stute N, Zander A, Kuck KH. Reduction of myocardial scar size after implantation of mesenchymal stem cells in rats: what is the mechanism? Stem Cells Dev. 2005; 14: 299-309.

112. Aupperle H, Garbade J, Schubert A, Barten M, Dhein S, Schoon HA, Mohr FW. Effects of autologous stem cells on immunohistochemical patterns and gene expression of metalloproteinases and their tissue inhibitors in doxorubicin cardiomyopathy in a rabbit model. Vet Pathol. 2007; 44: 494-503.

113. Nagaya $\mathbf{N}$, Kangawa $\mathbf{K}$, Itoh $\mathrm{T}$, Iwase $\mathrm{T}$, Murakami S, Miyahara Y, Fujii T, Uematsu M, Ohgushi H, Yamagishi M, Tokudome T, Mori H, Miyatake K, Kitamura S. Transplantation of mesenchymal stem cells improves cardiac function in a rat model of dilated cardiomyopathy. Circulation. 2005; 112: 1128-35.

114. Guo J, Lin GS, Bao CY, Hu ZM, Hu MY. Anti-inflammation role for mesenchymal stem cells transplantation in myocardial infarction. Inflammation. 2007; 30: 97-104.

115. Ohnishi S, Yanagawa B, Tanaka K, Miyahara Y, Obata H, Kataoka M, Kodama M, Ishibashi-Ueda H, Kangawa K, Kitamura S, Nagaya N. Transplantation of mesenchymal stem cells attenuates myocardial injury and dysfunction in a rat model of acute myocarditis. $J \mathrm{Mol}$ Cell Cardiol. 2007; 42: 88-97.

116. Okada H, Suzuki J, Futamatsu H, Maejima Y, Hirao K, Isobe M. Attenuation of autoimmune myocarditis in rats by mesenchymal stem cell transplantation through enhanced expression of hepatocyte growth factor. Int Heart J. 2007; 48: 649-61.

117. Zhou H, Jin Z, Liu J, Yu S, Cui Q, Yi D. Mesenchymal stem cells might be used to induce tolerance in heart transplantation. Med Hypotheses. 2008; 70: 785-7.

118. Wu GD, Nolta JA, Jin YS, Barr ML, Yu H, Starnes VA, Cramer DV. Migration of mesenchymal stem cells to heart allografts during chronic rejection. Transplantation. 2003; 75: 679-85.

119. Inoue S, Popp FC, Koehl GE, Piso P, Schlitt HJ, Geissler EK, Dahlke MH.
Immunomodulatory effects of mesenchymal stem cells in a rat organ transplant model. Transplantation. 2006; 81: 1589-95.

120. Yue WM, Liu W, Bi YW, He XP, Sun WY, Pang XY, Gu XH, Wang XP. Mesenchymal stem cells differentiate into an endothelial phenotype, reduce neointimal formation, and enhance endothelial function in a rat vein grafting model. Stem Cells Dev. 2008; 17: 785-93.

121. Vincentelli A, Wautot F, Juthier F, Fouquet 0 , Corseaux D, Marechaux S, Le Tourneau T, Fabre 0, Susen S, Van Belle E, Mouquet F, Decoene C, Prat A, Jude B. In vivo autologous recellularization of a tissue-engineered heart valve: are bone marrow mesenchymal stem cells the best candidates? J Thorac Cardiovasc Surg. 2007; 134: 424-32.

122. Poh KK, Sperry E, Young RG, Freyman T, Barringhaus KG, Thompson CA. Repeated direct endomyocardial transplantation of allogeneic mesenchymal stem cells: safety of a high dose, "off-the-shelf", cellular cardiomyoplasty strategy. Int J Cardiol. 2007; 117: 360-4.

123. Burt RK, Loh Y, Pearce W, Beohar N, Barr WG, Craig R, Wen Y, Rapp JA, Kessler J. Clinical applications of blood-derived and marrow-derived stem cells for nonmalignant diseases. JAMA. 2008; 299: 925-36.

124. Guillot PV, Cui W, Fisk NM, Polak DJ. Stem cell differentiation and expansion for clinical applications of tissue engineering. J Cell Mol Med. 2007; 11: 935-44.

125. Schallmoser K RA, Bartmann C, Rohde E, Kashofer K, Emberger W, Lanzer G, Linkesch W, Strunk D. Animal serum-free clinical scale propagation of human MSC. Transfusion. 2007; 47: S28A.

126. Vulliet PR, Greeley M, Halloran SM, MacDonald KA, Kittleson MD. Intra-coronary arterial injection of mesenchymal stromal cells and microinfarction in dogs. Lancet. 2004; 363: 783-4.

127. Chen SL, Fang WW, Ye F, Liu YH, Qian J, Shan SJ, Zhang JJ, Chunhua RZ, Liao LM, Lin S, Sun JP. Effect on left ventricular function of intracoronary transplantation of autologous bone marrow mesenchymal stem cell in patients with acute myocardial infarction. Am J Cardiol. 2004; 94: 92-5.

128. Katritsis DG, Sotiropoulou PA, Karvouni E, Karabinos I, Korovesis S, Perez SA, Voridis EM, Papamichail M. Trans- coronary transplantation of autologous mesenchymal stem cells and endothelial progenitors into infarcted human myocardium. Catheter Cardiovasc Interv. 2005; 65: 321-9.

129. Katritsis DG, Sotiropoulou P, Giazitzoglou E, Karvouni E, Papamichail M. Electrophysiological effects of intracoronary transplantation of autologous mesenchymal and endothelial progenitor cells. Europace. 2007; 9: 167-71.

130. Osiris therapeutics announces positive results in groundbreaking stem cell trial to treat heart disease. 2008. Available at: http://investor.osiris.com/events.cfm

131. Freyman T, Polin G, Osman H, Crary J, Lu M, Cheng L, Palasis M, Wilensky RL. A quantitative, randomized study evaluating three methods of mesenchymal stem cell delivery following myocardial infarction. Eur Heart J. 2006; 27: 1114-22.

132. Hou D, Youssef EA, Brinton TJ, Zhang P, Rogers P, Price ET, Yeung AC, Johnstone BH, Yock PG, March KL. Radiolabeled cell distribution after intramyocardial, intracoronary, and interstitial retrograde coronary venous delivery: implications for current clinical trials. Circulation. 2005; 112: $150-6$.

133. Safety and effectiveness of human mesenchymal stem cell injections for repairing heart damage in people who have had a heart attack and are undergoing surgery for coronary artery bypass grafting (PROMETHEUS). 2008. Available at: http:// clinicaltrials.gov/ct2/show/NCT00587990

134. Zhang H, Song P, Tang Y, Zhang XL, Zhao SH, Wei YJ, Hu SS. Injection of bone marrow mesenchymal stem cells in the borderline area of infarcted myocardium: heart status and cell distribution. J Thorac Cardiovasc Surg. 2007; 134: 1234-40.

135. Rosenzweig A. Cardiac cell therapy-mixed results from mixed cells. $N$ Engl J Med. 2006; 355: 1274-7.

136. Giordano A, Galderisi U, Marino IR. From the laboratory bench to the patient's bedside: an update on clinical trials with mesenchymal stem cells. J Cell Physiol. 2007; 211: 27-35.

137. He G, Zhang H, Wei H, Wang Y, Zhang X, Tang $Y$, Wei $Y$, Hu S. In vivo imaging of bone marrow mesenchymal stem cells transplanted into myocardium using magnetic resonance imaging: a novel method to trace the transplanted cells. Int $J$ Cardiol. 2007; 114: 4-10. 